\title{
Pengaruh Kompetensi dan Independensi Terhadap Kualitas Audit Aparat Inspektorat dalam Pengawasan Keuangan Daerah Di Provinsi Sulawesi Utara
}

\author{
Cristofer Sumiok \\ Winston Pontoh
}

\begin{abstract}
ABSTRAK
In presenting a good financial governance, the Local Government must be able to present the financial statements in accordance with the local government Permendagri 13 of 2006 and the Government Accounting Standards (SAP). To obtain these results certainly not out of the factors that support the implementation of the financial statements as rules / regulations, education, experience, commitment to employees, and supporting tools that support the creation of the ability of the involved parties in the preparation of the financial statements of Local Government.

The purpose of this research aim to know the influence of competence and independence with quality audit regional inspectorate officers as financial control in the province of North Sulawesi.

The Data was collected by survey with questionnaire contain list of question that have to fill by internal auditors in inspectorate as respondent. Technique data analyzing to the test the hypothesis by multiple linear regression using SPSS Ver 19.0.

The result by using $F$-test shows that competence $(X 1)$ and independence $(X 2)$ on the test result indicate that the variabel $F$ competence $(X 1)$ and independence (X2) has significant correlation with audit quality regional inspectorate officers in the province of north Sulawesi. the result of $F$ test shows that Fhit = 6,016 and Ftab with confidence level 95\% df1 (2) and df2 (46) is 2,81 at level significance $0,002<\alpha: 5 \%(0,05)$ it means Ha could accepted the result of t test show that pnly competence variables that has influence with audit quality in regional inspectorate officers in the province of north Sulawesi. $t$ hit, shows 3,864 $>t_{\text {tab }}$ 2,014 at level significance 0,000 $<0,05$ Independence variable shows thit 0,986 $<t_{\text {tab }} 2,014$ at level significance 0,329 $>0,05$ it means that independent variable didn't influence with audit quality regional inspectorate officer in the province of north Sulawesi.
\end{abstract}

Key Words : competence, independence 


\section{PENDAhuluan}

\subsection{Alasan Pemilihan Judul}

Kualitas audit yang dilaksanakan oleh aparat inspektorat Provinsi Sulawesi Utara saat ini masih menjadi perhatian masyarakat, karena masih banyaknya temuan audit yang tidak terdeteksi oleh aparat inspektorat sebagai auditor internal, akan tetapi ditemukan oleh auditor eksternal yaitu Badan Pemeriksa Keuangan (BPK). Berdasarkan hasil pemeriksaan terhadap Laporan Keuangan Pemerintah Daerah (LKPD). BPK masih menemukan adanya kegiatan yang merugikan keuangan negara di Provinsi Sulawesi utara, dan di sejumlah kabupaten/kota lain pada tahun 2010, bahkan di Kabupaten Minahasa Selatan dan Kota Manado mendapat Opini Tidak Wajar. Dalam laporan keuangan tersebut ditemukan masih adanya Temuan-temuan berupa ketidakpatuhan terhadap peraturan perundangundangan, kecurangan, ketidakpatuhan dalam pelaporan keuangan dan lemahnya pengendalian intern. Dengan adanya temuan BPK tersebut, berarti kualitas audit aparat inspektorat yang ada di kabupaten/ kota Sulawesi utara masih kurang baik.

Audit harus dilaksanakan oleh seseorang atau lebih yang memiliki keahlian dan pelatihan teknis yang cukup sebagai auditor. Auditor harus memiliki dan meningkatkan pengetahuan mengenai metode dan teknik audit serta segala hal yang menyangkut pemerintahan seperti organisasi, fungsi, program, dan kegiatan pemerintah (BPKP,2008). Keahlian auditor menurut Tampubolon (2005) dapat diperoleh melalui pendidikan dan pelatihan yang berkelanjutan serta pengalaman yang memadai dalam melaksanakan audit yang berkualitas.

Selain keahlian audit, seorang auditor juga harus memiliki independensi dalam melakukan audit agar dapat memberikan pendapat atau kesimpulan yang apa adanya tanpa ada pengaruh dari pihak yang berkepentingan (BPKP, 2008). Pernyataan standar umum kedua SPKN adalah: "Dalam semua hal yang berkaitan dengan pekerjaan pemeriksaan, organisasi pemeriksa dan pemeriksa, harus bebas dalam sikap mental dan penampilan dari gangguan pribadi, ekstern dan organisasi yang dapat mempengaruhi independensinya". Dengan pernyataan standar umum kedua ini, organisasi pemeriksa dan para pemeriksanya bertanggung jawab mempertahankan independensinya sedemikian rupa sehingga pendapat, simpulan, pertimbangan atau rekomendasi dari hasil pemeriksaan yang dilaksanakan tidak memihak dan dipandang tidak memihak oleh pihak manapun. Namun penelitian yang dilakukan oleh samelson et al dikutip oleh Efendy (2010) independensi tidak berpengaruh signifikan terhadap kualitas audit. Dengan pertimbangan diatas, peneliti tertarik untuk melakukan mengenai pengaruh kompetensi dan independensi terhadap kualitas audit inspektorat dalam pengawasan keuangan daerah khususnya di provinsi Sulawesi Utara.

Kuncoro Mudrajad (2003:124), jenis data dapat dibedakan menjadi dua jenis yaitu :

a. Data Kuantitatif yaitu data yang dapat diukur dalam suatu skala numerik (angka).

b. Data Kualitatif yaitu data yang tidak dapat diukur dalam skala numerik. Namun karena dalam statistik semua data harus dalam bentuk angka, maka data kualitatif umumnya dikuantitatifkan agar dapat diproses lebih lanjut.

Jenis data yang digunakan dalam penelitian ini adalah data kualitatif yang diperoleh dari respon tertulis ( kuesioner ) yang telah terstruktur dengan tujuan untuk mengumpulkan informasi dari auditor pada Inspektorat Provinsi Sulawesi Utara sebagai responden dalam penelitian ini.

Data primer dalam penelitian ini yaitu berupa wawancara dan kuisioner yang diantarkan pada auditor pada Inspektorat Provinsi Sulawesi Utara sedangkan data sekunder dalam penelitian ini diperoleh dari berbagai macam buku, jurnal dan sumber lain dengan kategori data eksternal.

Populasi adalah wilayah generalisasi yang terdiri atas objek atau subyek yang mempunyai kuantitas dan karakteristik tertentu yang ditetapkan oleh peneliti untuk dipelajari dan kemudian ditarik kesimpulannya (Sugiono,2004:55). Objek populasi dari penelitian ini adalah auditor pada Inspektorat Provinsi Sulawesi Utara, Inspektorat Kota Manado dan Inspektorat Kabupaten Minahasa Selatan.

Sampel adalah sebagian dari jumlah dan karakteristik yang dimiliki oleh populasi tersebut (Sugiono,2004:56). Metode pemilihan sampel adalah metode purposive sampling yang merupakan 
metode pengambilan sampel dengan didasarkan pada kriteria tertentu (Sekaran, 2003), yaitu: 1) Auditor internal pemerintah yang melaksanakan pekerjaan di bidang auditing 2) Auditor internal pemerintah yang telah lulus sertifikasi pembentukan auditor maupun belum, namun pernah mengikuti diklat sertifikasi.

Dalam usaha untuk melengkapi penulisan hasil penelitian ini, penulis memperoleh dan mengumpulkan data dan informasi melalui tahap-tahap sebagai berikut.

Penelitian lapangan (field research) adalah suatu penelitian dimana data diperoleh melalui penelitian langsung yang dilakukan pada perusahaan yang bersangkutan, dimana data yang diambil sebagian besar diperoleh dengan teknik pengumpulan data sebagai berikut.

1. Interview yaitu : Teknik pengumpulan data yang dilakukan dengan cara mengadakan wawancara langsung dengan pihak perusahaan mengenai data yang ada sangkut pautnya dengan masalah yang di bahas.

2. Observasi yaitu : Teknik pengumpulan data yang dilakukan dengan cara mengamati dan terjun langsung ke objek yang diteiliti dari suatu pelaksanaan kegiatan sehinggga dapat memperoleh bukti visual (fisik) mengenai pelaksanaan kegiatan tersebut.

3. Kuesioner yaitu : Teknik pengumpulan data yang dilakukan dengan cara membuat daftar pertanyaan untuk kemudian di isi oleh responden tempat diadakannya penelitian, untuk menilai secara lebih lanjut mengenai pengaruh Kompetensi, dan Independensi terhadap Kualitas Audit Aparat Inspektorat dalam Pengawasan Keuangan Daerah di Provinsi Sulawesi Utara.

\section{LANDASAN TEORI}

\subsection{Pengelolaan Keuangan Daerah}

pengelolaan keuangan daerah dibagi menjadi tiga proses besar. Tiga proses tersebut adalah perencanaan (termasuk didalamnya aktifitas penetapan APBD/Penganggaran), penatausahaan (proses pelaksanaan APBD) dan pelaporan (pertanggungjawaban APBD). Proses akuntansi merupakan bagian dari aktifitas pelaporan yang mengharuskan setiap pengguna anggaran/pengguna barang untuk melaporkan seluruh transaksi kedalam laporan keuangan. Struktur APBD terdiri dari penerimaan daerah yang dirinci berdasarkan urusan pemerintah daerah, organisasi, kelompok, jenis, objek dan rincian objek pendapatan.

\subsection{Audit Sektor Publik}

Secara etimologi, pemeriksaan (audit) berasal dari bahasa latin dengan kata "auderee” yang berarti mendengar. Mendengar yang efektif adalah sebuah aktivitas menyerap informasi dalam suatu media dengan menggunakan alat pendengaran yang diikuti dengan respon yang terprogram. Dengan demikian agar kegiatan mendengar terjadi maka: harus ada informasi, media, alat pendengaran dan harus direspon. Oleh karena itu dapat dikatakan bahwa pemeriksaan adalah suatu kegiatan menyerap, mengolah, dan merespon data yang dilakukan oleh pihak yang dapat dipercaya dan disampaikan kepada pihak yang berkepentingan untuk ditindaklanjuti. Terkait dengan praktek akuntansi sebuah entitas, auditing lebih dikenal sebagai suatu proses pengumpulan dan evaluasi bukti-bukti dari informasi yang dilakukan oleh orang yang kompeten dan independen, untuk menentukan dan melaporkan tingkat kesesuaian antara informasi tersebut dengan kriteria yang telah ditetapkan.. Arens dikutip oleh Murwanto, (2012).

\subsection{Pengawasan Keuangan Daerah}

Pengawasan atas penyelenggaraan pemerintah diperlukan untuk menjamin agar pelaksanaan kegiatan pemerintah berjalan sesuai dengan rencana dan sesuai dengan ketentuan perundang-undangan yang berlaku. Selain itu dalam rangka mewujudkan good governance dan clean governance, pengawasan juga diperlukan untuk mendukung penyelenggaraan pemerintah yang efektif dan efisien, transparan, akuntabel, serta bersih dan bebas dari praktik-praktik KKN. Pengawasan terhadap penyelenggaraan pemerintah tersebut dapat dilakukan melalui pengawasan melekat, pengawasan masyarakat, dan pengawasan fungsional (Chayat, 2004). 


\subsection{Kualitas Audit.}

De Angelo (dalam alim 2007) mendefinisikan kualitas audit sebagai probabilitas dimana seorang auditor menemukan dan melaporkan tentang adanya suatu pelanggaran dalam sistem akuntansi kliennya. dimana Hasil penelitiannya menunjukkan bahwa KAP yang besar akan berusaha untuk menyajikan kualitas audit yang lebih besar dibandingkan dengan KAP yang kecil. Sedangkan Deis dan Groux (dalam alim 2007) menjelaskan bahwa probabilitas untuk menemukan pelanggaran tergantung pada kemampuan teknis auditor dan probabilitas melaporkan pelanggaran tergantung pada independensi auditor.

\subsection{Kompetensi}

Pernyataan standar umum pertama (SPKN dalam paragraf 02 dan 03) adalah: "Pemeriksa secara kolektif harus memiliki kecakapan profesional yang memadai untuk melaksanakan tugas pemeriksaan". Dengan Pernyataan Standar Pemeriksaan ini semua organisasi pemeriksa bertanggung jawab untuk memastikan bahwa setiap pemeriksaan dilaksanakan oleh para pemeriksa yang secara kolektif memiliki pengetahuan, keahlian, dan pengalaman yang dibutuhkan untuk melaksanakan tugas tersebut. Oleh karena itu, organisasi pemeriksa harus memiliki prosedur rekrutmen, pengangkatan, pengembangan berkelanjutan, dan evaluasi atas pemeriksa untuk membantu organisasi pemeriksa dalam mempertahankan pemeriksa yang memiliki kompetensi yang memadai.

\subsection{Independensi}

Independensi merupakan standar umum nomor dua dari tiga standar auditing yang ditetapkan oleh Ikatan Akuntan Indonesia (IAI) yang menyatakan bahwa dalam semua yang berhubungan dengan perikatan, independensi dan sikap mental harus dipertahankan oleh auditor. Berdasarkan ketentuan yang dimuat dalam PSA (Pernyataan Standar Audit) No. 04 (SA Seksi 220), standar ini mengharuskan auditor bersikap independen, artinya tidak mudah dipengaruhi, karena ia melaksanakan pekerjaannya untuk kepentingan umum, dalam hal ini dibedakan dengan auditor yang berpraktik sebagai auditor intern. Dengan demikian, ia tidak dibenarkan memihak kepada kepentingan siapapun, sebab bagaimanapun sempurnanya keahlian teknis yang ia miliki, ia akan kehilangan sikap tidak memihak yang justru sangat penting untuk mempertahankan kebebasan pendapatnya.

\section{GAMBARAN UMUM OBJEK PENELITIAN}

Data penelitian yang digunakan dalam penelitian ini merupakan data primer yang diperoleh dengan menggunakan daftar pertanyaan (kuesioner) yang telah disebarkan melalui contact person kepada aparat Inspektorat Daerah Provinsi Sulawesi Utara. Inspektorat Kab Minahasa Selatan dan Kota Manado. pada tanggal 6 Desember 2011.

Tabel 3.1. Populasi dan Sampel

\begin{tabular}{|c|c|}
\hline Pemerintah Daerah & Jumlah Auditor Internal \\
\hline Pemerintah Prov Sulawesi Utara & 24 \\
\hline Pemerintah Kab Minahasa Selatan & $\mathbf{8}$ \\
\hline Pemerintah Kota Manado & 27 \\
\hline Total & 59 \\
\hline
\end{tabular}

Sampai dengan batas akhir pengembalian yakni tanggal 30 Desember 2011, dari 59 kuisioner yang disebarkan, 50 kuisioner yang kembali dan 9 kuisioner yang tidak kembali. Tingkat pengembalian (response rate) yang diperoleh adalah 84,7 \% sedangkan sisanya 16,3\% tidak kembali. Hal ini dikarenakan adanya pegawai yang belum kembali dari pemeriksaan audit di SKPD, Cuti dan 
dinas keluar kota pada saat penyebaran kuisioner dilakukan, akibatnya perantara tidak sempat memberikan kuesioner sampai batas waktu yang ditentukan.

\section{ANALISIS DAN EVALUASI}

\subsection{Pengaruh Kompetensi terhadap Kualitas Audit}

Hipotesis pertama menyatakan bahwa kompetensi berpengaruh terhadap kualitas audit. Hasil pengujian statistik menunjukkan $t_{\text {hitung }}$ variabel kompetensi (X1) diperoleh angka 3,864 $>t_{\text {tabel }}$ 2,014 dan nilai signifikansi variabel kompetensi $=0.000<0,05$, maka maka dapat dinyatakan bahwa Ho ditolak dan Ha diterima. secara parsial (variabel $\mathrm{X}_{1}$ ) Kompetensi berpengaruh terhadap kualitas audit (variabel Y).

Hasil pengujian hipotesis ini sejalan dengan pendapat Bonner dikutip oleh Alim (2007) menemukan bahwa bukti empiris bahwa auditor berpengalaman lebih banyak menemukan kesalahan atau item-item yang tidak umum dibandingkan auditor yang tidak berpengalaman. Berdasarkan uraian diatas dapat ditarik kesimpulan bahwa kompetensi auditor adalah pengetahuan, keahlian, dan pengalaman yang dibutuhkan auditor untuk dapat melakukan audit secara objektif, cermat dan seksama.

Hasil penelitian ini mendukung hipotesis pertama bahwa kompetensi berpengaruh terhadap kualitas audit. Hal ini berarti kualitas audit dapat dicapai jika auditor memiliki kompetensi yang baik. Kompetensi tersebut terdiri dari dua dimensi yaitu pengalaman dan pengetahuan. Auditor sebagai ujung tombak pelaksanaan tugas audit memang harus senantiasa meningkatkan pengetahuan yang telah dimiliki, agar penerapan pengetahuan dapat maksimal dalam praktiknya. Penerapan pengetahuan yang maksimal tentunya akan sejalan dengan semakin bertambahnya pengalaman yang dimiliki. Sesuai dengan standar umum bahwa auditor disyaratkan memiliki pengalaman kerja yang cukup dalam profesi yang ditekuninya, serta dituntut untuk memenuhi kualifikasi teknis dan berpengalaman dalam bidang industri yang digeluti kliennya (Arens dan Loebbecke, 1997). Dalam Alim (2007) Pengalaman juga akan memberikan dampak pada setiap keputusan yang diambil dalam pelaksanaan audit sehingga diharapkan setiap keputusan yang diambil adalah merupakan keputusan yang tepat. Hal tersebut mengindikasikan bahwa semakin lama masa kerja yang dimiliki auditor maka auditor akan semakin baik pula kualitas audit yang dihasilkan.

Hasil tersebut dapat dipahami bahwa untuk meningkatkan kualitas audit, seorang auditor sangat bergantung pada tingkat kompetensinya. Jika auditor memiliki kompetensi yang baik maka auditor akan dengan mudah melakukan tugas-tugas auditnya dan sebaliknya jika rendah maka dalam melaksanakan tugasnya, auditor akan mendapatkan kesulitan-kesulitan sehingga kualitas audit yang dihasilkan akan rendah pula.

\subsection{Pengaruh Independensi terhadap Kualitas Audit}

Hasil statistik pada analisis regresi linier berganda, dapat dilihat bahwa $t_{\text {hitung variabel }}$ Independensi (X2) diperoleh angka 0,986 < $\mathrm{t}_{\text {tabel }} 2,014$ dan nilai signifikansi variabel independensi (X2) 0,329 > 0,05 maka dapat dinyatakan bahwa Ho diterima dan Ha ditolak, Dengan demikian Independensi (variabel X2) Tidak berpengaruh terhadap kualitas audit.

Hasil pengujian hipotesis ini tidak sejalan dengan pendapat Tisnawati (2009) dan Deis dan Giroux, 1992 dalam Alim, (2007) yang menyatakan bahwa independensi berpengaruh terhadap kualitas audit, bahwa lama waktu auditor melakukan kerjasama dengan klien (tenure) berpengaruh terhadap kualitas audit. dan bahwa kemungkinan dimana auditor akan melaporkan salah saji tergantung pada independensi auditor. Namun demkian, hasil penelitian ini sejalan dengan Sukriah (2009), elfarini (2007), fachrudin (2008) Dan Efendy (2010) yang menyimpulkan bahwa independensi berpengaruh tidak signifikan terhadap kualitas audit, Karena banyaknya tekanan auditor yang berasal dari pribadi dan ekstern sehingga mengakibatkan kualitas audit yang dihasilkan rendah. Sehingga 
independensi yang dimiliki aparat inspektorat tidak menjamin apakah yang bersangkutan akan melakukan audit secara berkualitas.

Memang tidak mudah menjaga tingkat independensi agar tetap sesuai dengan jalur yang seharusnya. Diduga karena independensi aparat inspektorat masih terpengaruh dengan penentu kebijakan yang dapat mengintervensi hasil pemeriksaan, disamping itu Kerjasama dengan klien yang terlalu lama bisa menimbulkan kerawanan atas independensi yang dimiliki auditor karena auditor dan auditee sama-sama di lingkungan pegawai yang sama dalam hal ini provinsi Sulawesi utara sehingga menimbulkan hubungan interpersonal baik hubungan kekerabatan atau relasi kepentingan lainnya dan seringnya kepala daerah melakukan mutasi antar satuan kerja perangkat daerah. Belum lagi jika auditor melakukan pemeriksaan, mereka mendapatkan berbagai fasilitas yang disediakan auditee selama penugasan audit yang bisa saja mempengaruhi independensi dalam pemeriksaan, meskipun aparat acapkali mendapat fasilitas dari auditee, namun aparat tetap menganggap bahwa audit yang baik tetap harus dilaksanakan

\section{KESIMPULAN DAN SARAN}

\subsection{Kesimpulan}

Penelitian ini bertujuan untuk mengetahui pengaruh kompetensi, dan independensi, aparat Inspektorat Provinsi Sulawesi Utara terhadap kualitas audit. Berdasarkan hasil penelitian maka dapat diambil kesimpulan sebagai berikut.

1. Kompetensi dan Independensi, secara simultan berpengaruh terhadap kualitas audit yang dilaksanakan oleh aparat inspektorat. Dan Pengaruh ini di tinjau dari koefisien determinasi diperoleh sekitar $23.5 \%$ Sedangkan sisanya disebabkan oleh faktor-faktor lain.

2. Kompetensi berpengaruh terhadap kualitas audit, sehingga semakin baik tingkat kompetensi, seperti penguasaan standar akuntansi dan auditing, wawasan tentang pemerintahan dan pengalaman seperti yang didapat melalui diklat auditor internal maka akan semakin baik kualitas audit yang dilakukannya.

3. Independensi tidak berpengaruh terhadap kualitas audit, sehingga independensi yang dimiliki aparat inspektorat tidak menjamin apakah yang bersangkutan akan melakukan audit secara berkualitas. Karena banyaknya tekanan auditor yang berasal dari pribadi dan ekstern sehingga mengakibatkan kualitas audit yang dihasilkan rendah.

\subsection{Saran}

Berdasarkan hasil penelitian yang telah dilakukan maka diajukan saran, antara lain sebagai berikut.

1. Peneliti juga menyarankan untuk penelitian selanjutnya agar memperluas objek penelitian pada aparat inspektorat kabupaten/kota se-Provinsi Sulawesi utara, sehingga hasilnya dapat digeneralisasi.

2. Penentu kebijakan tidak boleh mempengaruhi independensi auditor dalam pemeriksaan untuk kepentingan pribadi atau golongan yang dapat merugikan negara, sehingga diharapkan kualitas audit yang dihasilkan oleh aparat Inspektorat dapat semakin baik.

3. Perbandingan antara kualitas audit sektor swasta dan sektor publik adalah bahwa kualitas audit di sektor publik lebih rendah dibandingkan kualitas audit di sektor swasta, namun hal ini perlu diuji kembali di Indonesia, apakah akan menghasilkan temuan yang sama.

\section{DAFTAR PUSTAKA}

Alim, M.N, T. Hapsari, dan L. Purwanti (2007), "Pengaruh Kompetensi dan Independensi terhadap Kualitas Audit dengan Etika Auditor sebagai Variabel Moderasi," Simposium Nasional Akuntansi X. Makassar.

Abdulloh, (2006), "Pengaruh Kompetensi dan Independensi Auditor Terhadap Kualitas Audit Pada Kantor Akuntan Publik di Makassar," Tesis Universitas Hasanudin 
Afiah, Nunuy Nur (2009), Pengaruh Kompetensi Anggota DPRD dan Kompetensi Aparatur Pemerintah Daerah terhadap Pelaksanaan Sistem Informasi Akuntansi. Universitas padjajaran , Jawa Barat.

BPKP, (2008), Kode Etik dan Standar Audit edisi kelima, Pusat Pendidikan dan Pelatihan Badan Pengawasan dan Pembangunan BPKP.

Cahyat, A (2004), "Sistem Pengawasan terhadap Penyelenggaraan Pemerintah Daerah Kabupaten. Pembahasan Peraturan Perundangan di Bidang Pengawasan," Governance Brief Number 3

Elvira, Zeyn (2011), "Akuntansi pemerintahan terhadap akuntabilitas keuangan dengan komitmen organisasi sebagai pemodernisasi"

Elfarini, E.C (2007), "Pengaruh Kompetensi dan Independensi Auditor terhadap Kualitas Audit," Universitas Negeri Semarang

Efendy, (2010), "Pengaruh Kompetensi, Independensi dan Motivasi terhadap Kualitas Audit Aparat Inspektorat dalam Pengawasan Keuangan Daerah," Tesis Universitas Diponegoro Semarang

Gujarati, Damodar (2003), Basic Econometrics, Fourth Edition, McGraw-Hill, New York.

Irawati, Nur (2011), “ Pengaruh Kompetensi dan Indepedensi Auditor Terhadap Kualitas Audit Pada Kantor Akuntan Publik". Unhas Makasar

Harhinto, T (2004), "Pengaruh Keahlian dan Independensi terhadap Kualitas Audit, Studi Empiris pada KAP di Jawa Timur," Tesis Universitas Diponegoro Semarang.

Haryanto, Sahmuddin, dan Arifuddin (2007), Akuntansi Sektor Publik. Edisi pertama, Badan Penerbit Universitas Diponegoro Semarang

Kuncoro, Mudrajat (2003), Metode Riset Untuk Bisnis dan Ekonomi, Penerbit Erlangga, Jakarta.

Kasidi, (2007), "Faktor-faktor yang mempengaruhi independensi auditor," Jawa Tengah

Mardiasmo, (2005), Akuntansi Sektor Publik Edisi 2. Penerbit Andi. Yogyakarta

Mayangsari, S (2003), "Pengaruh Keahlian Audit dan Independensi terhadap Pendapat Audit: Suatu Kuasieksperimen," Jurnal Riset Akuntansi Indonesia Vol. 6 No. 1. Januari

Mulyadi, (1992), Pemeriksaan Akuntan. Yogyakarta: Badan Penerbit STIE YKPN

Peraturan Badan Pemeriksa Keuangan Republik Indonesia Nomor 01 Tahun 2007. Standar Pemeriksaan Keuangan Negara. Jakarta

Peraturan Menteri Negara Pendayagunaan Aparatur Negara nomor PER/05/M.PAN/03/2008. Standar Audit Aparat Pengawasan Intern Pemerintah. Jakarta.

Murwanto, (2012), “ Audit Sektor Publik suatu pengantar bagi pembangunan akuntabilitas instansi pemerintah"

Sugiyono, (2008), Metode Penelitian Kuantitatif, Kualitatif, dan R\&D. Penerbit Alfabeta. Bandung.

Sri Lastanti, Hexana (2005), " Tinjauan Terhadap Kompetensi dan Independensi Akuntan Publik : Refleksi Atas Skandal Keuangan,” Media Riset Akuntansi, Auditing dan Informasi Vol.5 No.1 April 2005.

Siti NurMawar, (2010), "Pengaruh Kompetensi dan Independensi terhadap Kualitas Audit," Skripsi Universitas Negeri Semarang

Saifudin, (2008), "Pengaruh Kompetensi dan Independensi terhadap opini audit going concern," Skripsi Universitas Negeri Semarang

Sugiyono, (2004), Statistika Untuk Penelitian, Penerbit CV. Alfabeta, Bandung.

Sunarsip, (2001), Coorporat Governance Audit : Paradigma Baru Profesi Akuntansi dalam Mewujudkan Good Coorporate Gvernance, Media Akuntansi, No. 17/Th. VII.pp. II-VII

Tisnawati, (2009), "Pengaruh kompetensi, independensi dan etika auditor terhadap kualitas audit aparat inspektorat," Tesis Universitas Diponegoro 